\title{
MULTIMEDIA FUSION DALAM PERISIAN PENCERITAAN INTERAKTIF VISUAL BAGI APLIKASI SAINS PERINGKAT PRASEKOLAH
}

\author{
ROBIATUL A'DAWIAH JAMALUDDIN* \\ HALIMAH BADIOZE ZAMAN**
}

\begin{abstract}
Abstrak
Aplikasi pelbagai media ataupun multimedia fusion, merujuk kepada hubungan lebih daripada satu media seperti teks, grafik, animasi, audio dan video dalam pelbagai persekitaran digital seperti persekitaran maya, realiti luasan dan realiti campuran. Aplikasi tersebut berpotensi sebagai alat bantu pengajaran dan pembelajaran yang dapat meningkatkan kefahaman dan pencapaian murid prasekolah, terutamanya bagi topik yang berbentuk abstrak dan kompleks. Keputusan analisis statistik terhadap ujian pasca bagi Kumpulan kawalan (K) dan Kumpulan Eksperimen (E) mendapati, terdapat perbezaan pencapaian yang signifikan dalam pembelajaran topik sistem solar bertemakan Meneroka Angkasa di antara Kumpulan Eksperimen $(E)$ berbanding dengan Kumpulan Kawalan $(K)[t(d f=40)=2.895, p=0.008]$. Nilai min ujian pasca bagi Kumpulan Kawalan (K) ialah 9.571; dan nilai min ujian pasca bagi Kumpulan Ekperimen (E) ialah 11.381. Jadi, dapatan ini menunjukkan bahawa pencapaian murid dari Kumpulan Eksperimen (E) adalah lebih tinggi berbanding Kumpulan Kawalan (K).
\end{abstract}

Kata kunci: Pelbagai Media, Visual Infomasi, Penceritaan Menarik, Sains, Awal Persekolahan. 


\begin{abstract}
Multi-media applications or multimedia fusion, refers to the integration of more than one media such as text, graphic, animation, audio and video in multi digital environments such as virtual reality, augmented reality and mixed reality. These applications have potential to be effective teaching and learning aids that can enhance understanding and achievement of preschool learners, epecially on topics that are abstract and complex in nature. Results of the statistical analysis on the post test for the Controlled (K) and Experimental (E) groups, showed that there was a significant difference in the learning of the topic on Solar System with the theme Exploring Outerspace by the Experimental group (E) when compared to the Controlled group $(K) \quad[t(d f=40)=2.895, p=0.008]$. The mean indicated for the post test results by the Controlled group $(K)$ was 9.571; and the mean indicated for the post test results by the Experimental group $(E)$ was 11.381. Thus, these findings showed that the achievement of preschool learners from the Experimental group $(E)$ was higher as compared to learners from the Controlled group $(K)$.
\end{abstract}

Keywords: Multimedia Fusion, Informatic Visual, Interactive Storytelling, Science, Preschool.

* $\quad$ Pensyarah Kanan di Infrastructure University Kuala Lumpur

** Profesor Kanan di Institut Informatik Visual, Universiti Kebangsaan Malaysia

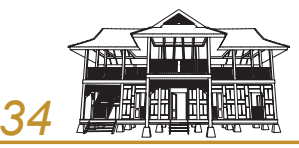




\subsection{Pengenalan}

Pelbagai media ditakrifkan dalam berbagai cara, bergantung kepada perspektif seseorang. Secara tipikal, pelbagai media (multimedia fusion) boleh disinonimkan dengan multimedia iaitu, kesepaduan pelbagai media (multimedia fusion), jalinan elemen seperti teks, numerik, grafik, imej, video, animasi dan suara dalam persekitaran digitaluntuk menyampaikan maklumat, bagi maksud pendidikan dan hiburan. Pelbagai media (multimedia fusion) seperti multimedia, realiti luaran dan visual 3D berkeupayaan mewujudkan interaktiviti bagi membolehkan pengguna mencapai maklumat tanpa mengikut turutan(Halimah \& Azlina, 1996).

Aplikasi pelbagai media (multimedia fusion) dijangka dapat meningkatkan dan membantu para murid menerima pengetahuan yang disampaikan, mengulangkaji, membuat latihan, mengukur pencapaian, serta terlibat dengan pengajaran dan pembelajaran dengan lebih aktif. Aplikasi pelbagai media (multimedia fusion) boleh membantu pelajar yang lemah(Leong, 1998). Namun demikian, tahap keberkesanan sesuatu aplikasi pelbagai media (multimedia fusion) seperti multimedia, realiti luasan dan visual 3D, bergantung kepada reka bentuk pembelajaran yang menjadi dasar binaan oleh perancang dan pembina sesuatu aplikasi pendidikan. Walaupun terdapat aplikasi pendidikan multimedia, realiti luasan dan visual 3D, terdapat aplikasi yang dibina gagal memberi kesan yang positif kepada para murid, tetapi jumlah yang berjaya masih lebih tinggi (Smith \& Hart, 2009).

Sebelum sesuatu aplikasi pendidikan berbentuk pelbagai media (multimedia fusion) dibina, kajian yang mendalam perlu dilaksanakan. Ini adalah kerana aplikasi pendidikan bukanlah satu-satunya penentu kepada keberhasilan pembelajaran. Terdapat pelbagai faktor lain yang terlibat seperti motivasi, sosial, ekonomi, latar belakang, persekitaran, kurikulum dan guru. Sesuatu aplikasi pendidikan hanya dapat memotivasikan para murid untuk belajar, tetapi aplikasi tersebut tidak mengajar murid, kerana yang mengajar murid adalah guru. Keberkesanan pembelajaran tidak bergantung kepada sesuatu media pengajaran, tetapi bagaimana aplikasi tersebut dapat digunakan. Perbezaan media juga, akan mempengaruhi tahap pengetahuan seseorang. Sekiranya murid dapat menguasai bahan pengajaran yang disampaikan melalui aplikasi tersebut, baharulah hasil sesuatu pembelajaran topik tercapai.

\subsection{Tinjauan Literatur}

Istilah cerita interaktif atau interactive storytelling mula dicipta oleh Chris Crawford, seorang penyelidik dan pembangun pembina aplikasi(Noble, 2009). Kajiannya mendapati bahawa cerita interaktif adalah berbeza dengan cerita linear yang konvensional. Cerita interaktif membenarkan pergerakan plot cerita tanpa mengikut turutan dengan pelbagai kemungkinan dalam dunia yang dramatik. Percubaan awal untuk memahami cerita interaktif dilakukan pada tahun 1970an, yang diusahakan oleh Roger Shanks melalui penyelidikannya di Universiti Northwestern. Aplikasi cerita interaktif yang pertama diterbitkan

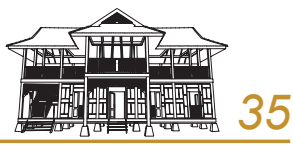


ialah Façade, yang dicipta oleh Michael Mateas dan Andrew Stern. Façade telah dikomersialkan dalam tahun 2006(Gordon, 2003).

Lazimnya, pembina aplikasi menggunakan model cerita interaktif untuk membina aplikasi sains berbentuk permainan komputer, filem ataupun realiti maya. Pembina likasi sains boleh menggunakan pelbagai media (multimedia fusion) pengajaran seperti multimedia, realiti luasan, dan visual 3D, untuk menyediakan jalan cerita secara tanpa berjujukan (non-linear)(Steiff, 2011). Pergerakan daripada satu lapisan ke lapisan lain, bergantung kepada tindakan murid. Murid perlu terlibat secara aktif. Bagi cerita interaktif berasaskan reka bentuk permainan, penyelesaian masalah ataupun pencarian jawapan murid perlu berinteraksi dengan sistem secara aktif untuk meneruskan pelajaran (Safko, 2010). Murid juga kerap diajukan berbagai soalan dan diberikan arahan yang memerlukan tindakan murid.

Hasil kajian lalu menyenaraikan empat(4)kategoricerita interaktifiaitu murid bebas melakukan penjelajahan, jalan cerita yang sukar diduga, akhiran cerita ditentukan oleh tindakan murid dan meninggalkan kesan yang mendalam kepada murid(Tomin, 2008). Cerita interaktif bagi tujuan pembelajaran mata pelajaran sains untuk murid prasekolah dipelopori oleh Disney. Jadi, kelebihan cerita digital interaktif untuk pengajaran sains membolehkan murid melibatkan diri mereka di dalam perjalanan cerita tersebut(Mei \& Andre, 2011). Ini membuatkan mereka lebih terlibat secara aktif dan dapat mengekalkan pelajaran yang disampaikan secara lebih berkesan. Cerita dipaparkan mengikut arahan murid melalui penggunaan peranti input seperti tetikus, papan kekunci, skrin sentuh dan kayu ria. Teknologi ini telah menukar konsep penceritaan interaktif secara konvensional di mana murid belajar secara pasif kepada konsep penceritaan interaktif secara digital, yang mana murid belajar secara aktif. Terdapat tujuh (7) elemen penceritaan iaitu tema, plot, watak, latar, sudut pandangan, gaya dan nada.

\subsection{Sampel Kajian}

Sampel kajian merupakan murid prasekolah dari sebuah sekolah diNegeri Sembilan. Faktor utama sekolah ini dipilih adalah kerana ia memiliki dua (2) kelas prasekolah dan tenaga pengajarnya mengamalkan budaya ICT dalam pengajaran dan pembelajaran.Jadual 1 menunjukkan demografi taburan dalam kajian ini.

Jadual 1: Demografi Taburan Murid Prasekolah

\begin{tabular}{cccc}
\hline Kumpulan & Perempuan & Lelaki & Jumlah \\
\hline Kawalan (K) & 11 & 10 & 21 \\
Eksperimen (E) & 9 & 12 & 21 \\
Jumlah & 20 & 22 & 42 \\
\hline
\end{tabular}




\subsection{Prototaip Aplikasi MyScience}

Prototaip aplikasi MyScience mengandungi empat (4) cerita bersiri yang direka bentuk dan dibangunkan khas untuk pendidikan sains melalui tema Meneroka Angkasa. Persembahan prototaip aplikasi bermula dengan skrin pembukaan, diikuti dengan skrin pilihan ataupun skrin Menu Utama, yang mana murid boleh memilih modul yang hendak dipelajari. Aliran struktur hierarki aplikasi MyScience dapat dilihat dalam Rajah 1

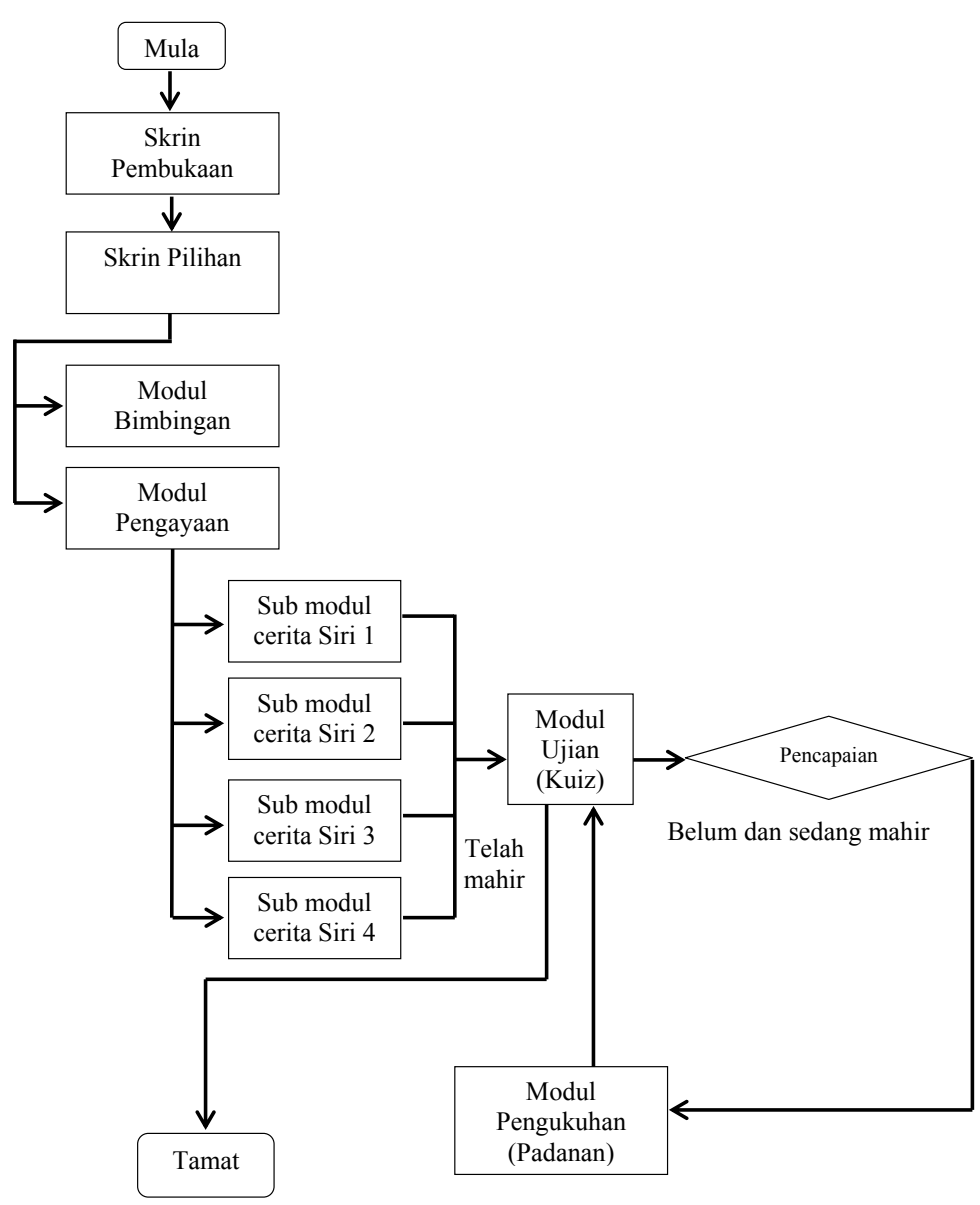

Rajah 1: Aliran Struktur Hierarki Aplikasi MyScience 
Aplikasi MyScience mempunyai empat (4) modul utama iaitu Modul Bimbingan, Modul Pengayaan, Modul Pengukuhan dan Modul Ujian. Aplikasi tersebut yang masih dalam bentuk prototaip, dibangunkan untuk membantu murid prasekolah memahami sains cakerawala bertemakan Meneroka Angkasa. Aplikasi tersebut direka bentuk dengan menerapkan teori pembelajaran Gagne yang mana strategi pembelajaran direka supaya bermula daripada sesuatu yang lebih mudah kepada yang lebih kompleks. Contoh yang dimuatkan ke dalamnya menunjukkan aplikasi MyScience juga, menerapkan pendekatan konstektual yang relevan dengan kehidupan seharian murid. Pendekatan pembelajaran secara tidak langsung ini merupakan satu cara untuk mengaitkan pengetahuan cakerawala melalui imej visual, dengan kehidupan seharian murid, dan seterusnya menjadikan pembelajaran lebih menarik dan bermakna. Ini dapat meningkatkan proses pembelajaran dan mampu mengekalkan tumpuan murid terhadap pembelajaran yang disampaikan dengan mengaitkan bahan pembelajaran kepada kehidupan seharian mereka, seperti yang ditunjukkan dalam Rajah 2. 

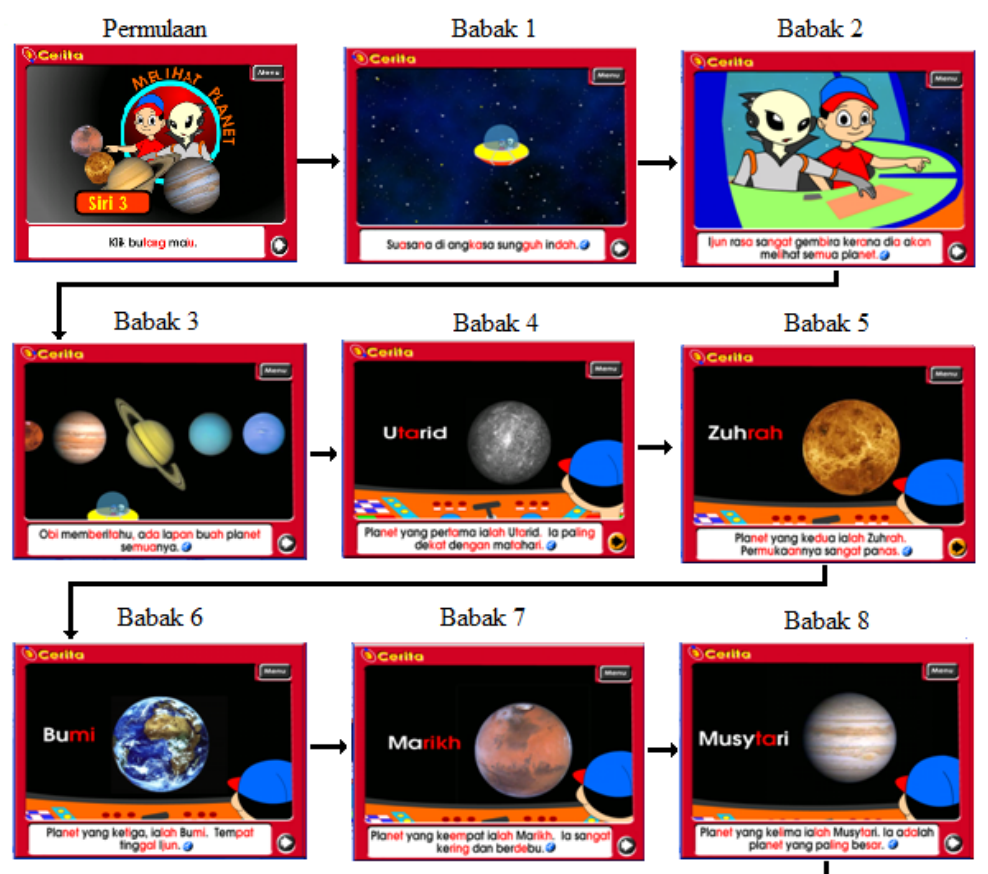

Babak 7

Babak 8
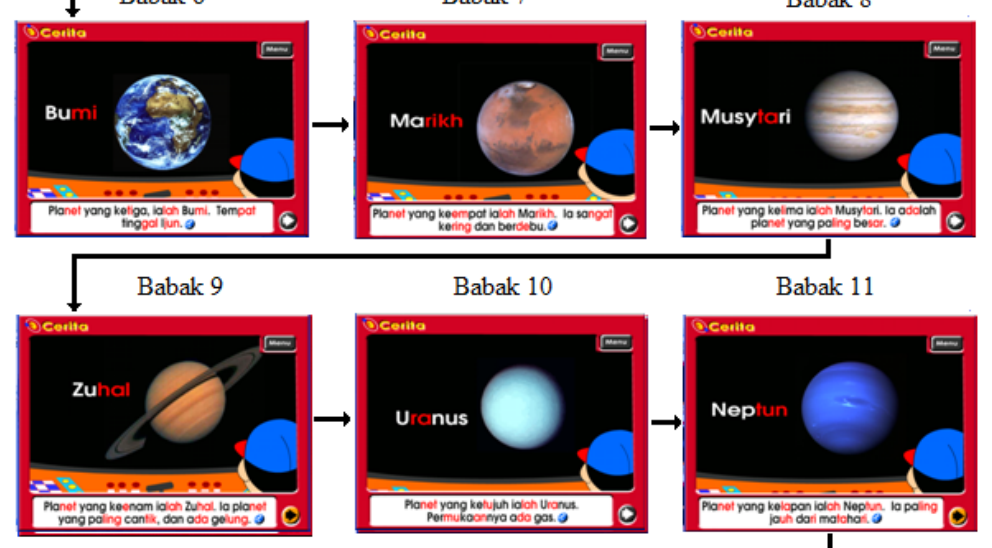

Babak 11

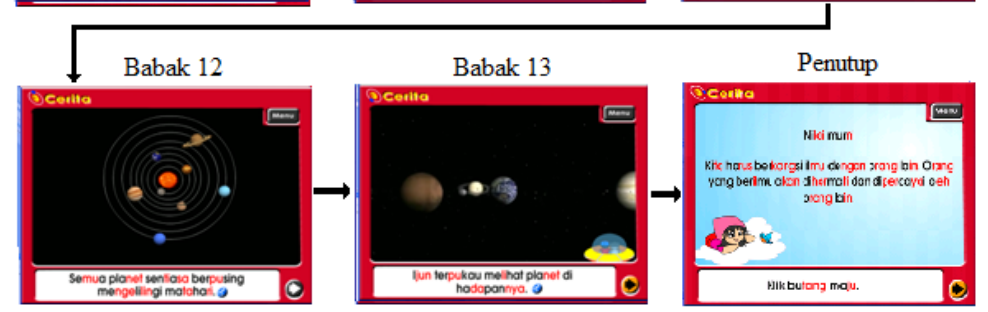

Rajah 2: Pembelajaran berpendekatan penceritaan interaktif visual Dapatan Kajian Ujian Pra dan Pasca 
Data yang diperoleh dari Ujian Pra dan Pasca diproses dengan menggunakan perisian Microsoft Excel 2010 dan juga 'Statistical Packages for the Social Science' (SPSS) versi 16.0. Pelajar daripada Kumpulan Kawalan (K)yang diajar dengan menggunakan kaedah pengajaran dan pembelajaran konvensional dilabelkan dengan huruf $\mathrm{K}$, diikuti dengan nombor 1 hingga 21; sementara pelajar daripada Kumpulan Eksperimen (E) yang diajar dengan menggunakan aplikasi MyScience pula, dilabelkan dengan huruf E, juga diikuti dengan nombor 1 hingga 21. Ujian Pra dan Pasca dilaksanakan untuk menilai prestasi kemahiran murid melakukan proses sains berasaskan tema Meneroka Angkasa iaitu memerhati. Skala penilaian adalah seperti yang dapat dilihat dalam Jadual 2.

Jadual 2 Skala Perkembangan Murid Prasekolah

\begin{tabular}{lcccc}
\hline \multirow{2}{*}{ Standard Prestasi (SPTS) } & \multicolumn{2}{c}{ Kumpulan K } & \multicolumn{2}{c}{ Kumpulan E } \\
& Bilangan & Peratus & Bilangan & Peratus \\
\hline BM & 13 & 62 & 12 & 57 \\
SM & 5 & 24 & 7 & 33 \\
TM & 3 & 14 & 2 & 10 \\
Jumlah & 21 & 100 & 21 & 100 \\
\hline
\end{tabular}

Jadual 3 menunjukkan perbezaan prestasi pencapaian bagi kemahiran memerhati di antara murid daripada Kumpulan Kawalan (K) dan Kumpulan Eksperimen (E) dalam Ujian Pra. Analisis Ujian Pra terhadap Kumpulan Kawalan (K) menunjukkan terdapat tiga orang murid (14\%) dari Kumpulan Kawalan (K) mencapai tahap TM, lima orang murid (24\%) mencapai tahap SM; dan 13 orang murid $(62 \%)$ mencapai tahap BM. Manakala Ujian Pra bagi Kumpulan Eksperimen (E), menunjukkan terdapat dua orang murid (10\%) mencapai tahap TM; tujuh orang murid (33\%) mencapai tahap SM; dan 12 orang murid (57\%) mencapai tahap BM. 
Jadual 3 Pencapaian Kemahiran Memerhati bagi Ujian Pra

\begin{tabular}{lcl}
\hline $\begin{array}{c}\text { Skor } \\
\text { (Tahap } \\
\text { Penguasaan) }\end{array}$ & Simbol & \multicolumn{1}{c}{ Kriteria } \\
\hline Telah Menguasai & TM & $\begin{array}{l}\text { Tahu dan boleh melaksanakan proses sains dengan } \\
\text { sendiri secara baik dan bertatasusila. }\end{array}$ \\
Sedang Maju & SM & $\begin{array}{l}\text { Tahu dan boleh melaksanakan dengan bimbingan sedikit } \\
\text { daripada guru/penyelidik. } \\
\text { Tahu beberapa perkara asas (yang minimum) berkaitan } \\
\text { Bengan proses sains tetapi tidak boleh melaksanakan } \\
\text { sendiri (sentiasa memerlukan bimbingan) }\end{array}$ \\
\hline
\end{tabular}

Dapatan kajian ini, menunjukkan bilangan murid yang lemah dalam kemahiran memerhati masih tinggi kerana hanya lima orang murid (12\%) mencapai tahap TM, manakala 12 orang murid (29\%) mencapai tahap SM, dan 25 orang murid (60\%) mencapai tahap BM. Rajah 3 menunjukkan corak taburan tahap kemahiran (TM, SM dan BM) untuk Ujian Pra bagi kedua-dua kumpulan. Corak taburan tahap kemahiran tidak menunjukkan jurang perbezaan yang besar. Ini bermakna, murid (responden) daripada kedua-dua kumpulan adalah homogen, iaitu seimbang dari segi tahap pencapaian terhadap kemahiran memerhati dalam tema Meneroka Angkasa. 


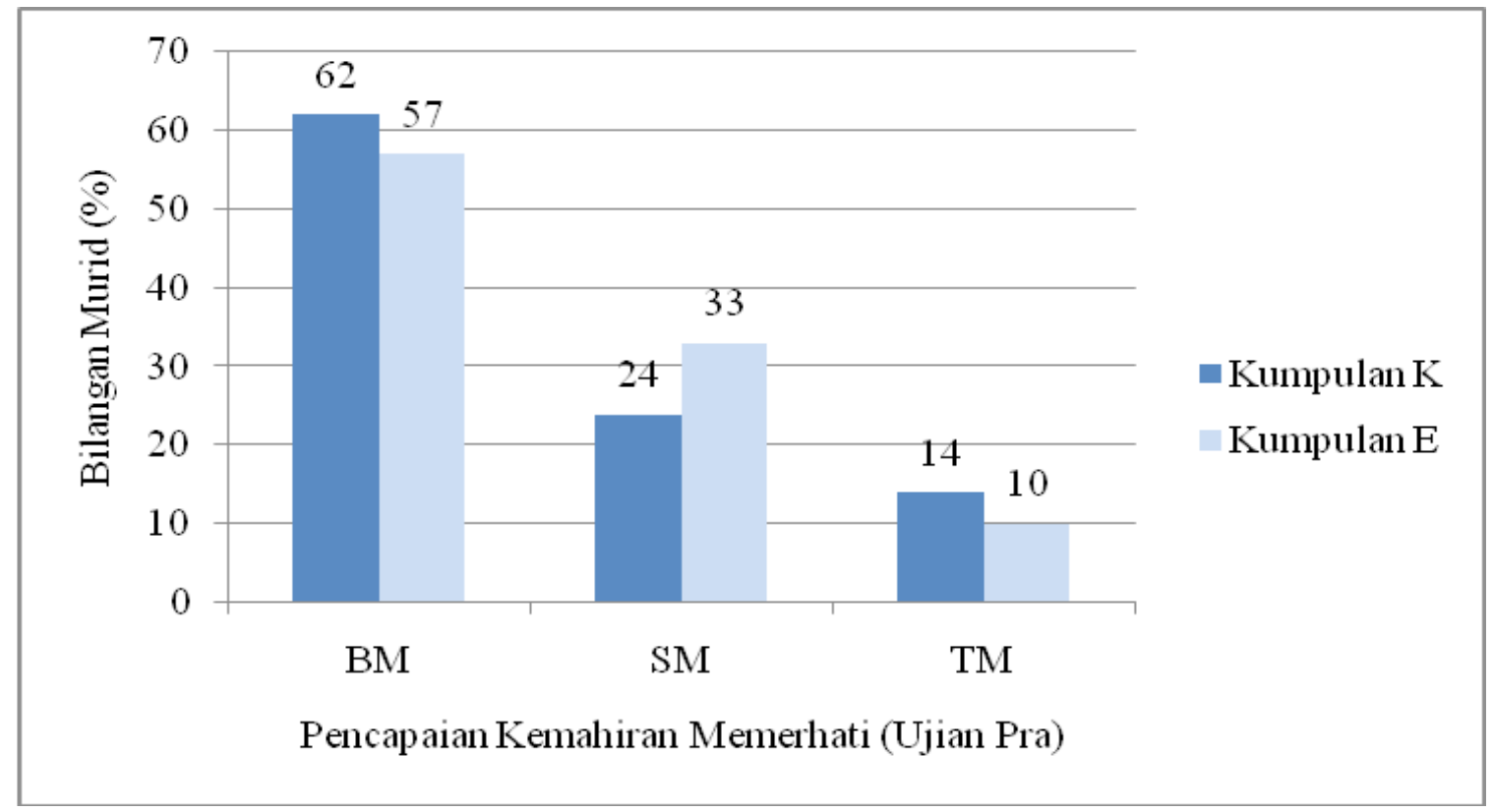

Rajah 3: Taburan Pencapaian Kemahiran Memerhati bagi Ujian Pra

Manakala Jadual 4 menunjukkan perbezaan prestasi pencapaian bagi kemahiran memerhati di antara murid daripada Kumpulan Kawalan (K) dan murid daripada Kumpulan Eksperimen (E) dalam Ujian Pasca. Analisis Ujian Pasca terhadap Kumpulan Kawalan (K) menunjukkan terdapat 10 orang murid (48\%) dari Kumpulan Kawalan (K) mencapai tahap TM, empat orang murid (19\%) mencapai tahap SM, dan tujuh orang murid $(33 \%)$ mencapai tahap BM. Manakala Ujian Pasca yang dilaksanakan oleh Kumpulan Eksperimen (E) menunjukkan terdapat 14 orang murid (67\%) mencapai tahap TM; enam orang murid (29\%) mencapai tahap SM; dan seorang murid (5\%) mencapai tahap BM. Dapatan kajian menunjukkan peningkatan yang sangat baik dalam kemahiran memerhati kerana bilangan murid yang mencapai tahap TM adalah tinggi iaitu 24 orang murid (57\%), manakala 10 orang murid $(24 \%)$ mencapai tahap SM, dan hanya lapan orang murid (19\%) mencapai tahap BM. 
Jadual 4: Pencapaian Kemahiran Memerhati bagi Ujian Pasca

\begin{tabular}{lcccc}
\hline \multirow{2}{*}{ Standard Prestasi (SPTS) } & \multicolumn{2}{c}{ Kumpulan K } & \multicolumn{2}{c}{ Kumpulan E } \\
& Bilangan & Peratus & Bilangan & Peratus \\
\hline BM & 7 & 33 & 1 & 5 \\
SM & 4 & 19 & 6 & 29 \\
TM & 10 & 48 & 14 & 67 \\
Jumlah & 21 & 100 & 21 & 100 \\
\hline
\end{tabular}

Rajah 4 menunjukkan corak taburan tahap kemahiran (TM, SM dan BM) untuk Ujian Pasca bagi keduadua kumpulan. Corak taburan tahap kemahiran menunjukkan jurang perbezaan yang besar. Pencapaian murid daripada Kumpulan Eksperimen (E) menunjukkan keputusan yang lebih baik berbanding murid daripada Kumpulan Kawalan (K). Ini kerana bilangan murid Kumpulan Eksperimen (E) yang mencapai tahap TM adalah lebih tinggi berbanding murid daripada Kumpulan Kawalan (K). Kumpulan Kawalan (K) memiliki tujuh orang $(33 \%)$ murid pada tahap BM, berbanding Kumpulan Eksperimen (E) yang hanya memiliki seorang $(5 \%)$ murid pada tahap BM. Analisis ini menunjukkan bahawa kaedah penggunaan aplikasi multimedia fusion MyScience yang diaplikasikan kepada Kumpulan Eksperimen (E) adalah lebih berkesan, berbanding kaedah konvensional yang diaplikasikan kepada Kumpulan Kawalan (K), bagi meningkatkan prestasi pencapaian dalam kemahiran memerhati bagi topik Sistem Solar, bertemakan Meneroka Angkasa.

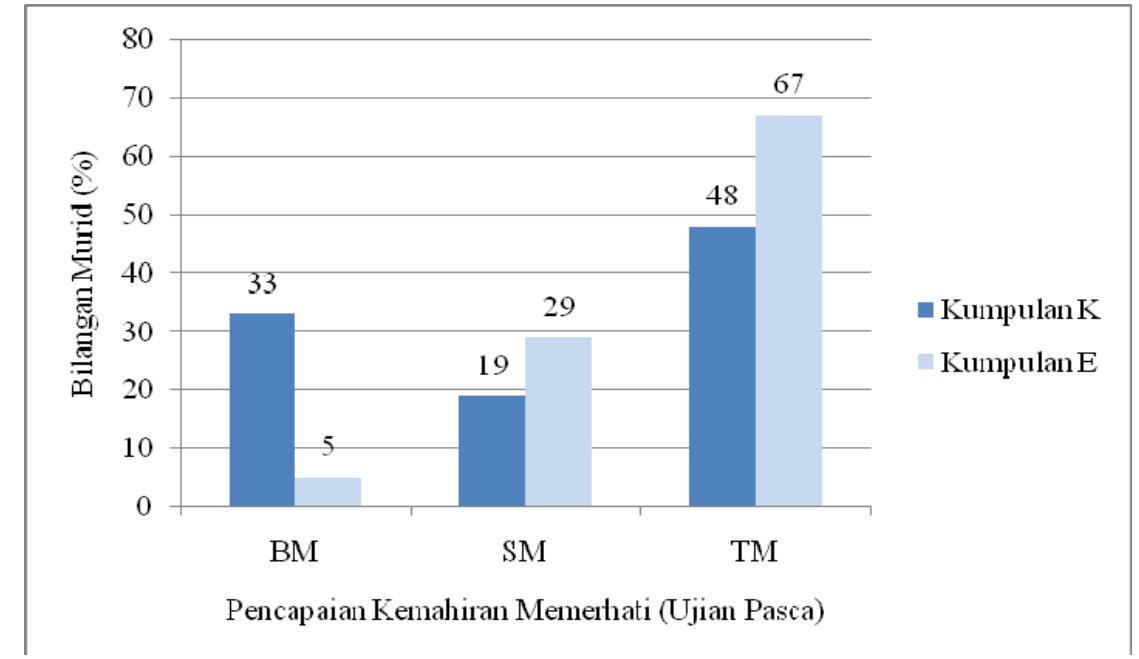

Rajah 4 : Taburan Pencapaian Kemahiran Memerhati bagi Ujian Pasca 
Ujian-t Sampel Berpasangan pada Jadual 5, dilaksanakan untuk membanding keputusan Ujian Pra Kumpulan Kawalan (K) dan Kumpulan Eksperimen (E). Keputusan Ujian-tadalah signifikan $[\mathrm{t}(\mathrm{df}=40)=.0001$, $p=1.00]$, nilai min Ujian Pra $(M=5.52, S P=1.72)$, manakala Ujian Pasca $(M=5.52, S P=1.25)$. Sisihan piawai adalah kecil kerana kurang daripada 1, manakala nilai p pula adalah lebih besar daripada 0.05 , maka hipotesis nol diterima. Analisis ujian mendapati tidak terdapat perbezaan yang signifikan di antara keputusan Ujian Pra Kumpulan Kawalan (K) dan Kumpulan Eksperimen (E).

Jadual 5: Analisis Ujian-t Berpasangan untuk Ujian Pra bagi Kumpulan Kawalan (K) dan Kumpulan Eksperimen (E)

\begin{tabular}{lllccc}
\hline \multicolumn{1}{c}{ Pemboleh Ubah } & N & Min & Sisihan Piawai & t & p \\
\hline Ujian Pra K & 21 & 5.52 & 1.72 & \multirow{2}{*}{001} & \multirow{2}{*}{1.00} \\
Ujian Pra E & 21 & 5.52 & 1.25 & & \\
\hline
\end{tabular}

Ujian-t Sampel Berpasangan pada Jadual 6, dilaksanakan untuk membanding keputusan Ujian Pasca Kumpulan Kawalan (K) dan Kumpulan Eksperimen (E). Keputusan Ujian-t adalah signifikan [t $(\mathrm{df}=40)=2.90$, $\mathrm{p}=0.008$ ], nilai min Ujian Pra $(M=9.57, \mathrm{SP}=2.69)$, manakala Ujian Pasca $(\mathrm{M}=11.38, \mathrm{SP}=0.97)$. Sisihan piawai adalah kecil kerana kurang daripada 1 , manakala nilai p pula adalah lebih kecil daripada 0.05 , maka hipotesis nol ditolak. Analisis ujian mendapati terdapat perbezaan yang signifikan di antara keputusan Ujian Pasca Kumpulan Kawalan (K) dan Kumpulan Eksperimen (E).

Jadual 6 : Analisis Ujian-t berpasangan untuk Ujian Pasca bagi Kumpulan Kawalan (K) dan Kumpulan Eksperimen (E)

\begin{tabular}{lccccc}
\hline \multicolumn{1}{c}{ Pemboleh Ubah } & N & Mean & Sisihan Piawai & t & p \\
\hline Ujian Pasca (K) & 21 & 9.57 & 2.69 & 2.89 & 0.008 \\
Ujian Pasca (E) & 21 & 11.38 & .97 & & \\
\hline
\end{tabular}


Keputusan analisis statistik dengan menggunakan Ujian-t terhadap keputusan Ujian Pra dan Pasca bagi Kumpulan Kawalan (K) dan Kumpulan Eksperimen (E) menunjukkan kesan pencapaian yang signifikan. Namun demikian, pencapaian murid daripada Kumpulan Eksperimen (E) adalah lebih tinggi berbanding Kumpulan Kawalan (K). Keputusan Ujian-t mendapati terdapat perbezaan pencapaian yang signifikan dalam peningkatan kemahiran melakukan proses sains (memerhati) bagi topik Sistem Solar, bertemakan Meneroka Angkasa di antara murid daripada Kumpulan Eksperimen (E) berbanding dengan murid daripada Kumpulan Kawalan (K).

\subsection{Kesimpulan}

Segala modul yang dibina dalam aplikasi MyScience mengandungi unsur penting yang menyokong perkembangan kemahiran proses sains dalam topik Sistem Solar bertemakan Meneroka Angkasa. Kemahiran proses sains perlu dikuasai oleh setiap individu, termasuk murid prasekolah, kerana proses sains tersebut dapat membantu mereka dalam setiap tugasan harian dan penemuan ilmu baharu. Kemahiran melakukan proses sains juga akan mengembangkan pemikiran saintifik dan literasi saintifik di kalangan murid, yang akhirnya membawa kepada kecemerlangan akademik dan profesional(Hamlin \& Wisneski, 2012).Pada era ekonomi pengetahuan digital ini, sains merupakan pengetahuan dan kemahiran yang perlu diperoleh semua masyarakat. Masyarakat perlu memperkukuhkan kemahiran dan memperkayakan minda mereka dengan pengetahuan sains supaya menjadi masyarakat yang berdaya saing, analitikal, kritikal dan beretika. Disebabkan pendidikan sains adalah penting, maka penyelidikan ini dilaksanakan bagi memupuk kemahiran proses sains pada peringkat awal iaitu prasekolah. 


\section{Rujukan}

Gordon, A., 2003. Experience Management Using Storyline Adaptation Strategies. Proceeding of the First International Conference on Technologies for Interactive Digital Storytelling and Entertainment. Germany: : Taylor and Francis.

Halimah, B., \& Azlina, A., 1996. New Review of Children Literature and Librarianship. Using Computer Graphics to Encourage Reading with the BAWAL Programme, 22-44.

Hamlin, M., \& Wisneski, D., 2012. Supporting the scientifik thinking and inquiri of toddlers and preschoolers through. National Association for the Educational of Young Children (NAEYC), (pp. 82-88).

Leong, M., 1998. Pengajaran dan Pembelajaran Kimia Organik dalam Mata Pelajaran Kimia Melalaui Perisian Laman Web. Tesis Sarjana. Bangi: Universiti Kebangsaan Malaysia.

Mei, S., \& Andre, E., 2011. Interactive Storytelling. 4th International Conference on Interactive Digital Storytelling, (pp. 152-157). Vancouver.

Noble, J., 2009. Interactivity: A designer's guide to processing Arduino, and Openframeworks. O’Reilly Media.

Safko, L., 2010. The social media bible: Tactics, tools, and strategies for business success (3 ed.). Indianapolis: Wiley Publishing.

Smith, P., \& Hart, C., 2009. Wiley-Blackwell Handbook of Childhood Social Development. New Jersey: John Wiley \& Sons.

Steiff, J., 2011. Sherlock Holmes and philosophy: The Footprints of a Gigantic Mind (Popular Culture and Philosophy). Open Court.

Tomin, M., 2008). Interactive Storytelling in Entertaining. Retrieved 2013, from http://www.cs.uu.nl/docs/ vakken/ani/Papers2008/Wk6-Tomin-Liu_vs2.pdf 


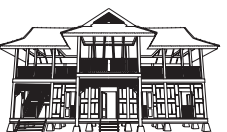

DENIAD 